\title{
Temporary immersion biorreators: efficient technique for the propagation of the 'Pircinque' strawberry
}

\author{
Samila Silva Camargo ${ }^{1}$, Leo Rufato ${ }^{2}$, Maicon Magro ${ }^{3}$, André Luiz Kulkamp de Souza ${ }^{4}$
}

Abstract - The in vitro propagation technique via temporary immersion bioreactors is a tool that, through the culture in a liquid medium, allows an increase in the efficiency of seedling production. Several researches with the strawberry crop have shown greater efficiency of the system compared to the conventional process of micropropagation in solid medium. In this sense, the objective herein was to establish a protocol of multiplication and rooting of the 'Pircinque' strawberry, in temporary immersion bioreactors. Two distinct and independent studies were carried out, characterized by the multiplication and rooting stages of strawberry explants, newly introduced and registered in Brazil. Two culture media (MS and KNOP) were studied and, as a control treatment, the growth of the explants in solid culture medium was evaluated with the addition of $5 \mathrm{~g} \mathrm{~L}^{-1}$ of agar. Different immersion times of the culture medium were explored: five or eight times a day, for 15 minutes. The study was composed of the culture medium and immersion time factors, as well as the control (solid) treatment. It was verified that the use of temporary immersion bioreactors system is an efficient technique for the multiplication and rooting of explants of strawberry cv. Pircinque, when compared to the conventional method of micropropagation with the use of solid culture medium, making it possible to optimize the production of seedlings in biofactories. The MS liquid medium, in contact with explants of 'Pircinque' strawberry five times a day, increased the growth of the aerial part and the root system.

Index Terms: Fragaria Ananassa; micropropagation; automation; liquid medium.

\section{Biorreatores de imersão temporária: técnica eficiente para a propagação de morangueiro 'Pircinque'}

Corresponding author: samilasc@yahoo.com.br

Received: August 31, 2018 Accepted: November 27, 2018

Copyright: All the contents of this journal, except where otherwise noted, is licensed under a Creative Commons Attribution License.

\section{$(\mathrm{cc}) \mathrm{E} \mathbf{Y}$}

Resumo - A técnica de propagação in vitro de explantes através de biorreatores de imersão temporária é uma ferramenta que possibilita, a partir do cultivo em meio líquido, aumentar a eficiência da produção de mudas. Diversas pesquisas com a cultura do morangueiro mostraram a maior eficiência do sistema quando comparado ao processo convencional da micropropagação, em meio sólido. Nesse sentido, o objetivo foi estabelecer um protocolo de multiplicação e enraizamento de morangueiro 'Pircinque', em biorreatores de imersão temporária. Realizaram-se dois estudos distintos e independentes, caracterizados pelas etapas de multiplicação e enraizamento de explantes de morangueiro recém-introduzidos e registrados no Brasil. Foram estudados dois meios de cultura (MS e KNOP) e, como tratamento-testemunha, foi avaliado o crescimento dos explantes em meio de cultivo sólido, com a adição de $5 \mathrm{~g} \mathrm{~L}^{-1}$ de ágar. Tempos distintos de imersão do meio de cultura em contato com os explantes foram estudados: cinco ou oito vezes ao dia, durante 15 minutos. O estudo compreendeu os fatores meio de cultura e tempo de imersão, assim como o tratamentotestemunha (sólido). Verificou-se que o uso de sistema de biorreatores de imersão temporária é uma técnica eficiente para a multiplicação e enraizamento de explantes de morangueiro cv. Pircinque, quando comparada ao método convencional de micropropagação com uso de meio de cultura sólido, possibilitando otimizar a produção de mudas em biofrábricas. O meio de cultivo MS líquido, em contato cinco vezes ao dia com explantes de morangueiro 'Pircinque', favorece o crescimento da parte aérea e do sistema radicular.

Termos para indexação: Fragaria Ananassa; micropropagação; automatização; meio líquido.

\footnotetext{
'Dr. Agronomic Engineer, Centro de Ciências Agroveterinárias, Universidade do Estado de Santa Catarina (CAV-UDESC). Lages-SC, Brasil. E-mail: samilasc@yahoo.com.br (ORCID 0000-0002-0659-1361)

${ }^{2}$ Dr. Agronomic Engineer, Centro de Ciências Agroveterinárias, Universidade do Estado de Santa Catarina. (CAV-UDESC). Lages-SC, Brasil. E-mail: leoruffato@yahoo.com.br (ORCID 0000-0001-9545-7035)

${ }^{3}$ MSc. Agronomic Engineer, Centro de Ciências Agroveterinárias, Universidade do Estado de Santa Catarina. (CAV-UDESC). Lages-SC, Brasil. E-mail: maicomagro@hotmail.com (ORCID 0000-0003-4889-6291)

${ }^{4}$ Dr. Agronomic Engineer, Empresa de Pesquisa Agropecuária e Extensão Rural de Santa Catarina, Estação Experimental de Videira. Videira-SC, Brasil andreluizks@yahoo.com.br (ORCID 0000-0003-4889-6291)
} 


\section{Introduction}

The increasing demand for species of economic importance has led to the search for the production of high-quality seedlings (with homogeneity, genetic and phytosanitary control) in a short period of time, through biotechnological tools. For this reason, in vitro propagation has proven to be a highly effective method for the production of a large number of plants (GEORGIEVA et al., 2016) and can be used for several species.

One of the strategies for in vitro cultivation, according to Camolesi et al. (2010) is related to the consistency of the culture medium, which may be one of the factors contributing to cost reduction. The use of liquid medium has provided results equal to or even better than those of the solid medium for several plant species because it allows greater contact of the vegetative material with the nutrients (FRÓMETA et al., 2017), thus providing an increase in productivity and efficiency in the propagation process.

The use of temporary immersion bioreactors is a tool that provides greater success in the production of in vitro seedlings. This system is an option for the production of large scale seedlings compared to conventional micropropagation, since it has advantages such as: acceleration and increase of multiplication and productivity rates, uniformity of production, reduction of labor and, consequently, total cost per unit due to the automated system (DEBIASI, 2011), thus, it has been successfully used in the micropropagation of species of economic interest (WILKEN et al., 2014).

Studies have reported that the productive efficiency with the use of bioreactors, when adequate protocols are established, is significantly superior to the conventional system of micropropagation (DEBIASI, 2011). However, species and cultivars require specific protocols as they may present different results under the same cultivation condition. Based on this, Frómeta et al. (2017) emphasize that studies are needed to evaluate the efficiency of the technique or the factors to be adjusted for each particular species, cultivar or genotype. In this sense, it is necessary to determine the efficiency of the multiplication and rooting of different selections of strawberry from the use of temporary immersion bioreactors, in order to verify the culture medium, use of growth regulators and the interval of time in which the materials are in contact with the liquid culture medium.

In strawberries, some pioneering studies have been performed, such as Hanhineva et al. (2005) who tested the 4-minute immersion system every 5 hours and different plant regulators and obtained positive results on the multiplication of the explants, as well as, Debnath (2017), who concluded that the temporary immersion system is efficient for the propagation of this species.

The 'Pircinque' strawberry cultivar was launched by a breeding program run by the CREA-FRF research institute, in Italy. The first generation of the plants was obtained in 2006 due to characteristics such as rusticity, growth habit, large fruits and with soluble solids and pulp firmness values (BARUZZI et al., 2017; FAEDI et al., 2014). Since then, these attributes of the new cultivar, protected and registered in Brazil, are already being studied in the different conditions of the country.

The objective of this research was to establish a protocol for the multiplication and rooting of the Italian 'Pircinque' strawberry cultivar in temporary immersion bioreactors to achieve high efficiency of the seedling production system.

\section{Material and methods}

The experiment was carried out at the Plant Biofactory, in the city of Lages/SC, belonging to the State University of Santa Catarina (CAV/UDESC). Two independent studies were carried out, characterized by the stages of multiplication and rooting of 'Pircinque' strawberry explants, both evaluated after 45 days.

The initial plant materials used were from plants already grown in vitro in MS culture medium (Figure 4). The tests were carried out under aseptic conditions in horizontal laminar flow chambers, and all the other instruments (tweezers, scalpels and petri plates) autoclaved and flambéed. The fifth-generation explants were standardized with four leaves each and a length of $2.5 \pm 0.2 \mathrm{~cm}$.

For both experiments, a temporary immersion system with double flasks (5-liter polyethylene bottles - Figure 1) was used, containing $300 \mathrm{~mL}$ of culture medium and 20 explants per bottle. In the automated system, the bottle hoses were connected to an air compressor, which was triggered via timer, so that from time to time the liquid culture medium was sent to the other flask where the 'Pircinque' propagules were found. For asepsis of the vials, sodium hypochlorite (2.5\%) was added inside the same, remaining in contact for seven days. The sterilization of the culture medium, as well as the hoses, lids and filters (porosity of $0.2 \mu \mathrm{m}$ and diameter of $64 \mathrm{~mm}$ ) used in the bioreactor system were autoclaved at $121^{\circ} \mathrm{C}$ and $1.5 \mathrm{~atm}$ for 20 minutes.

Two culture media, MS and KNOP (Figure 4)., already used cultivation of species under different protocols were studied. Both were composed of the salts and vitamins characteristic of each, $37.3 \mathrm{mg} \mathrm{L}^{-1}$ of Fe-EDDHA (ethylenediamine-di-o-hydroxyphenylacetic acid iron chelate), $0.25 \mathrm{mg} \mathrm{L}^{-1}$ of $\mathrm{GA}_{3}$ (Gibberellic acid) and $30 \mathrm{~g} \mathrm{~L}^{-1}$ of sucrose, with the difference in the two steps being the presence of $1 \mathrm{mg} \mathrm{L}^{-1}$ of BAP 
(6-Benzylaminopurine) in the multiplication and 0,05 $\mathrm{mg} \mathrm{L}^{-1}$ of BAP and $1 \mathrm{mg} \mathrm{L}^{-1}$ of IBA (Indole-3-butyric acid) in rooting. In addition, as a control treatment, the growth of explants in solid culture medium (MS and $\mathrm{KNOP}$ ) was evaluated, with the addition of $5 \mathrm{~g} \mathrm{~L}^{-1}$ of agar, as well as the other components already mentioned above. Different immersion times, five (every 4.8 hours) or eight (every 3 hours) a day for 15 minutes, of the explants in the culture medium were also studied. Thus, the study comprised the culture medium and immersion time factors, as well as the control treatment (solid MS and KNOP), totaling six treatments with three replicates of 20 explants each.

Independent of the phase under study, the flasks with the explants were kept in a growth room with a 16hour photoperiod, temperature of $25 \pm 2^{\circ} \mathrm{C}$ and luminous intensity of $27 \mu \mathrm{mol} \mathrm{m} \mathrm{m}^{-2} \mathrm{~s}^{-1}$.

The variables analyzed in the multiplication experiment were: number of shoots and leaves, explant length and mean length of shoots and callus size ( 0 to $2)$, considering 0 : no callus, 1 : small callus $(<1 \mathrm{~cm})$ and 2: large callus $(>1 \mathrm{~cm})$. In the rooting stage, in addition to the variables mentioned above, the number and length of the largest root, and the mean root length, were evaluated. Analyses comprising explant length and callus size were measured using a millimeter ruler.

Data were analyzed for normality and homogeneity by the Shapiro-Wilk and Bartlett tests. Afterwards, they were submitted to analysis of variance from the $F$ test and the averages, when statistically significant, were compared by the Tukey test at $5 \%$ probability. The values from counting were transformed into the square root of $\mathrm{x}+0.5[\sqrt{ }(\mathrm{x}+0.5)]$ and the scale referring to callus size in $\log (\mathrm{x}+\mathrm{K})$, where $\mathrm{x}$, is the mean obtained from each variable and $\mathrm{K}$ equal to 1 .

\section{Results and discussion}

From Tukey's test $(p<0.05)$, it was verified that the number of shoots and callus intensity were not influenced by the interaction of the factors (culture medium $\mathrm{x}$ immersion times of the culture medium), only isolated (Table 1).

In the MS culture medium, a higher number of shoots occurred compared to KNOP. Moreover, larger callus sizes were evident in the explants due to the multiplication rate favored by the components present in the MS culture medium, considered very rich in macronutrients, micronutrients and vitamins (DEZAN et al., 2012), aiding in the propagation of strawberry explants. As for the number of new shoots, the explants immersed in liquid medium $5 \mathrm{x} /$ day stood out in relation to the $8 \mathrm{x} /$ day treatment, followed by the solid medium. Therefore, the use of temporary immersion bioreactors (5x/day) led to a greater multiplication rate (around 56\%) when compared to the control system, without use of liquid medium and automated system. This conclusion is justified by Georgiev et al. (2014), who determined that the shorter immersion period provides longer exposure of the explants to the air, which increases the multiplication efficiency, since complete immersion of the tissues can cause malformation and/or loss of material due to asphyxiation or hyperhydricity.

Regarding the size of callus present in explants, those cultured in liquid medium and immersed 5x/day presented higher calogenic indices, but did not differ from cultivation in solid medium (Table 1). This variable is of great importance because in conditions of high callus formation, there may be an impairment in the proliferation of axillary buds and shoot lengthening, which affects the in vitro development, especially in conditions of direct propagation (NAVROSKI et al., 2013). This demonstrates that there was a beginning of cell division at the base of the explants; however, it does not guarantee that the formation of new buds, shoots and/or roots will occur, since it depends on the hormonal balance of the culture medium that will be absorbed by the in vitro plants.

Figure 2 shows the number of leaves of the explants, where the interaction of the two studied factors occurred, with higher formation of new leaves in the MS culture medium with immersion $5 x$ /day. In addition, regardless of whether or not the temporary immersion system was used, the MS culture medium was always superior to KNOP, with better results in $5 \mathrm{x} /$ day, $8 \mathrm{x} /$ day and conventional (solid) systems treatments, respectively.

Figure 2 also shows data for explant length and average length of 'Pircinque' strawberry shoots, with the highest length of explants always being obtained in the MS culture medium, regardless of the time of immersion in the bioreactors and in the control treatment. In the same figure, the average length of shoots is verified, being higher in MS in the automated system, in the two different immersion times, and the solid medium had the lowest values. The efficiency of the automated system in strawberry and raspberry tree trials has also been proven by Georgieva et al. (2016), where they concluded that the increase of the fresh weight of the explants in temporary immersion bioreactors was significant and the authors characterize this increase mainly due to the accumulation of water resulting from the liquid culture medium.

In the rooting stage of 'Pircinque' there were no interactions between the two factors for the following variables: number of shoots, mean root length, length of the largest root and callus size at the base of the explants (Table 2). The first two variables presented equal results, at the level of $5 \%$ probability of error. In relation to the culture medium used, MS provided explants with higher number of shoots, as well as average length of the largest root. The number of sprouts in immersion in liquid culture 
medium $5 \mathrm{x} /$ day or $8 \mathrm{x} /$ day was superior than the treatment of the conventional micropropagation system in solid culture medium by about $21 \%$, which demonstrates that bioreactors provide aeration conditions and renewal of the nutrients that characterize a more intense growth of the 'Pircinque' explants.

The mean root length, presented in Table 2, was not influenced by the two culture media studied. However, the contact of the nutrients to the explants immersed five times a day favored the average growth of the new roots formed during the rooting stage, followed by the $8 \mathrm{x} /$ day and solid treatments. Similar behavior to that obtained in this study was observed by Georgieva et al. (2016), where the protocol of rooting in liquid medium for strawberries proved to be efficient, since, in all explants studied, root formation occurred. The results of Gao et al. (2015) corroborate these, where the authors highlight the benefits in root development, coupled with good survival rates of explants grown in temporary immersion bioreactors, especially when compared to conventional methods.

The presence of callus was altered only in function of the presence of liquid or solid medium, where the conventional method, with agar, caused calli of larger size. Some authors highlight the disadvantages of a high occurrence of calli in the base of the explants, where they can prevent or interfere with the formation of roots and even, after the period of in vitro cultivation, may hinder the survival of the seedlings in the field due to the poor vascular connection between the stem and the roots (FOGAÇA et al., 2010).

The average number of leaves and roots (Figure 3A) was influenced by the cultivation method (traditional in a solid medium and in bioreactors with liquid medium) and by the two distinct culture media (MS and KNOP). A larger number of leaves were obtained in explants grown in a temporary immersion bioreactor system, regardless of the frequency of contact with the MS culture medium (five or eight times). Again, the use of the nutrients of the MS medium was significantly favorable for the root development of 'Pircinque' strawberry roots, but more prominently when it was kept in contact with the explants five times per day. These data do not corroborate the results of Oliveira et al. (2014), who concluded that in the majority of cases, the smaller intervals between the immersions favored the development of the cultures by the greater use of the liquid culture medium by the plant.

Figure 3A shows explant and shoot growth $(\mathrm{cm})$, where explant length was higher under immersion conditions of $5 \mathrm{x}$ /day in liquid MS culture medium. This same treatment also favored the average length of shoots, but did not differ from the presence of MS 8x/day. Thus, for the two variables, the use of temporary immersion bioreactors was once again superior to the control, that is, the conventional technique used in micropropagation of plants.

It is verified that for both the average number of leaves and roots, the bioreactor system of temporary immersion of liquid culture medium favored the development of 'Pircinque' strawberry explants. According to Oliveira et al. (2014), this result confirms that root proliferation depends on the availability of water and nutrients in the surrounding microenvironment. In this sense, if this microenvironment is low in nutrients or very dry, root growth is slow, and, as conditions improve, root growth tends to increase (TAIZ and ZEIGER, 2013).

Based on the results presented in this research, it is verified that although the use of a solid medium is the most common in the micropropagation technique, the liquid culture from the temporary immersion bioreactor system has the capacity to potentiate and significantly increase the rates of multiplication, as well as to reduce production costs when compared to the conventional method (DEBNATH et al., 2014). Thus, in spite of the need for specific studies for different cultivars, the automated system with liquid medium is indicated for the vegetative propagation of strawberries, especially when commercial and large-scale production of seedlings of the species is sought (DEBNATH et al. 2017). These results suggest that the production of seedlings in biofactories can occur in a technically efficient manner, making it possible to supply micropropagated seedlings directly to producers, with genetic and sanitary guarantees capable of leveraging the strawberry sector in the country. 

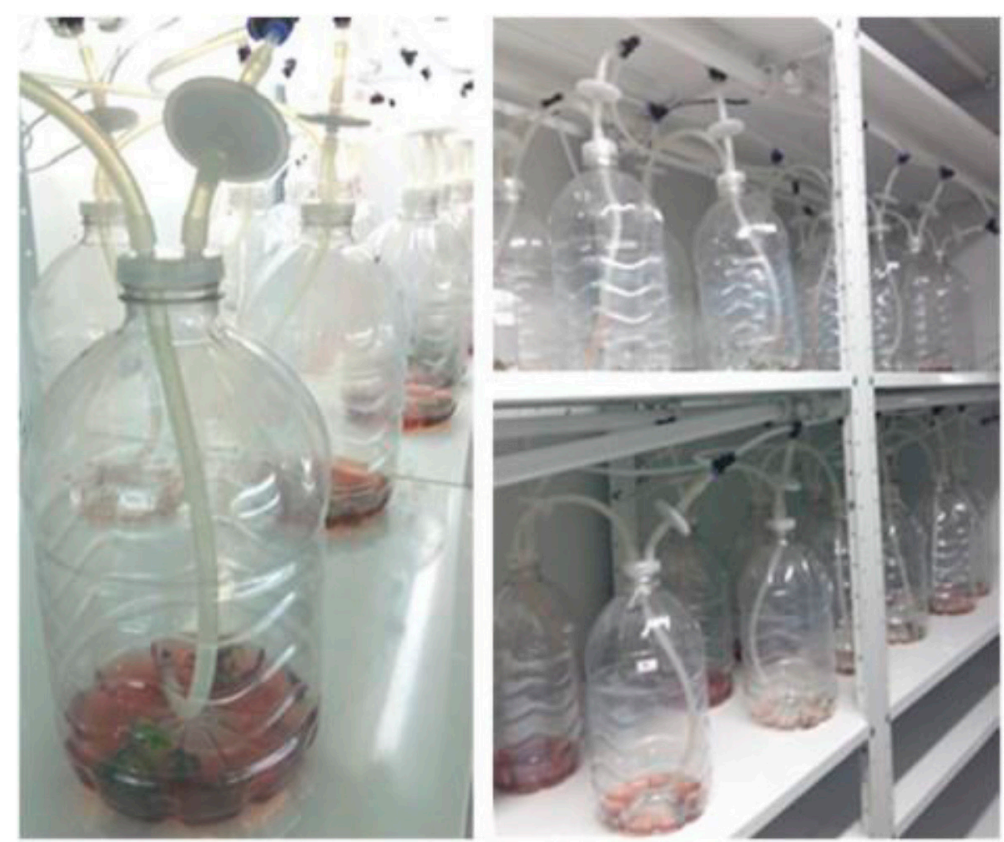

Figure 1. A system of temporary immersion bioreactors in double flasks for multiplication and rooting of 'Pircinque' strawberry explants, on the left, explants in contact with the culture medium and on the right, a view of the complete system, where the liquid medium is in the flask without explants.
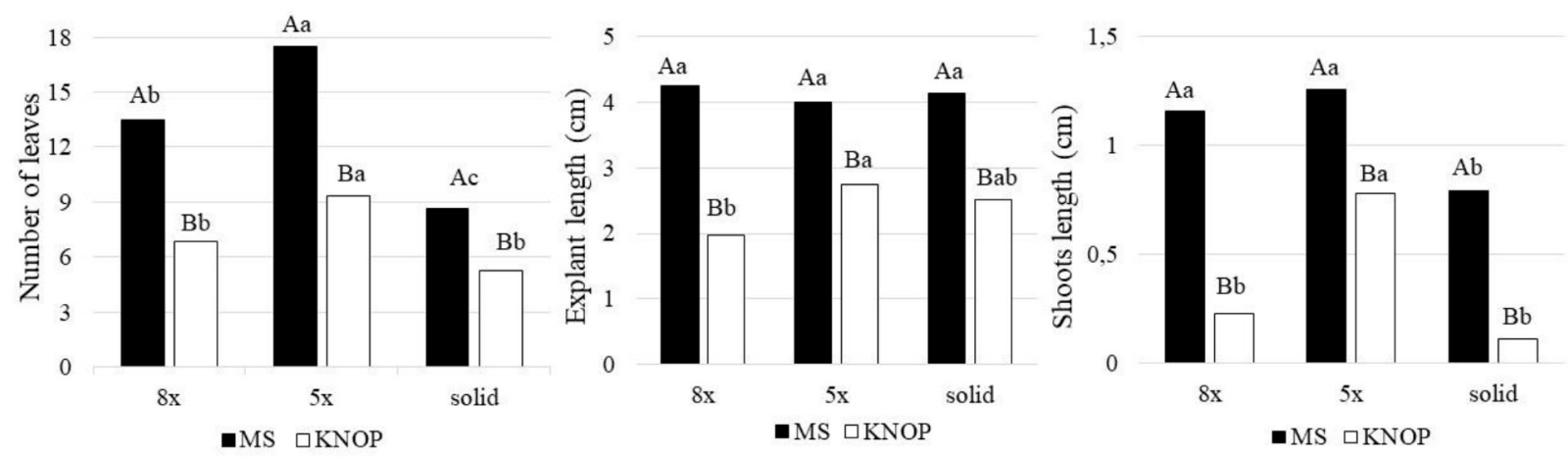

Figure 2. Number of leaves, length of explant and average length of shoots $(\mathrm{cm})$ in explants of 'Pircinque' strawberry multiplied in temporary immersion bioreactors. 

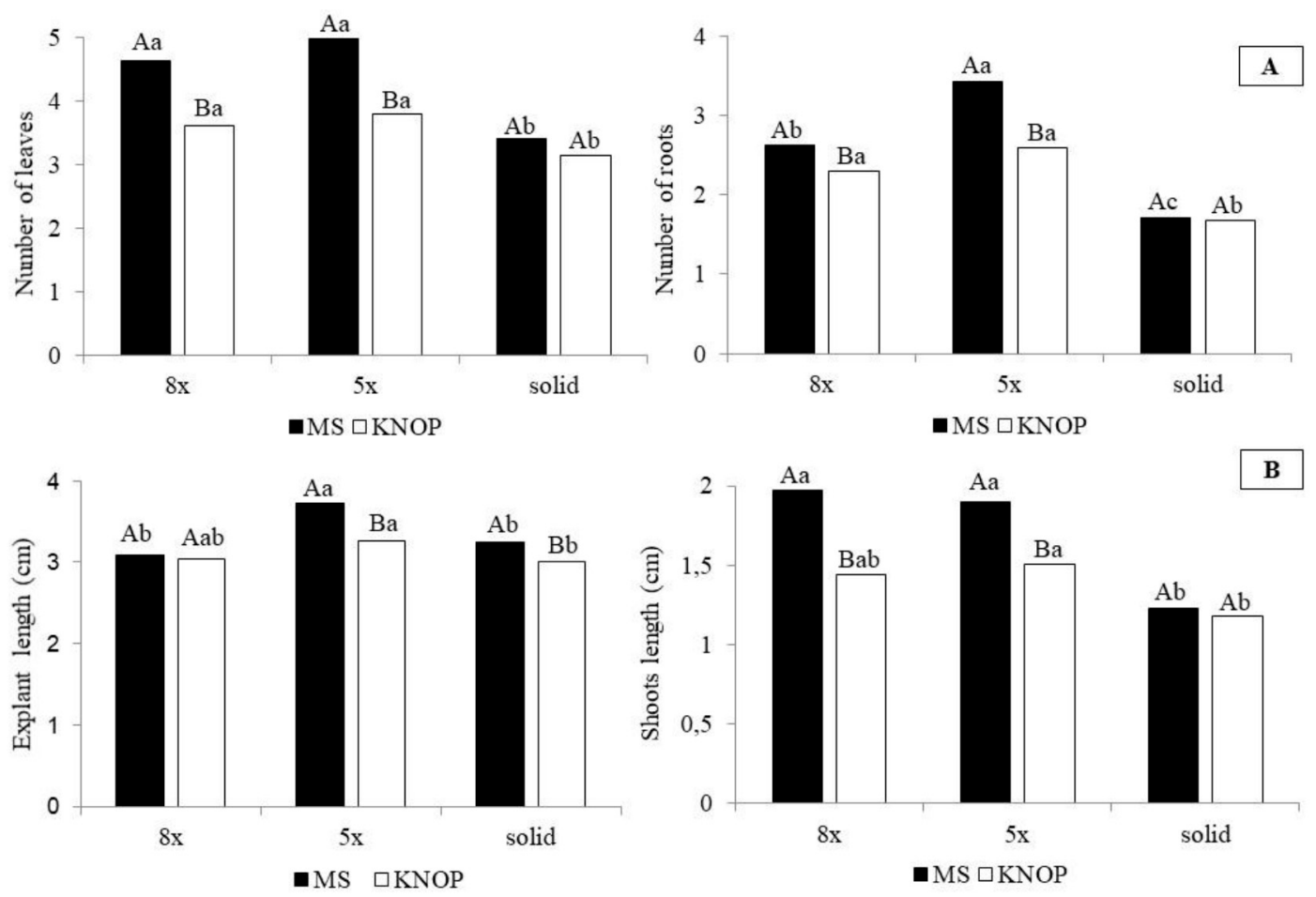

Figure 3. Average number of leaves and roots (A) and length of explant and shoots in $\mathrm{cm}$ (B) of 'Pircinque' strawberry explants during rooting phase in temporary immersion bioreactors.

* Significant by the Tukey test at 5\% probability of error; uppercase letters compare the culture media and the lowercase, immersion times in liquid solution.

Table 1. Number of shoots and callus size ( 0 to 2$)$ in 'Pircinque' strawberry explants multiplied in temporary immersion bioreactors.

\begin{tabular}{clccc} 
& \multicolumn{3}{c}{ Number of shoots } & \multicolumn{2}{c}{ Callus Size } \\
& \multicolumn{3}{c}{ Culture medium } \\
MS & 3.65 & $\mathrm{a}^{*}$ & 1.65 & $\mathrm{a}$ \\
$\mathrm{KNOP}$ & 1.35 & $\mathrm{~b}$ & 1.40 & $\mathrm{~b}$ \\
\hline \multicolumn{5}{c}{ Immersion times } \\
$5 \mathrm{x} / \mathrm{dia}$ & 3.59 & $\mathrm{a}$ & 1.69 & $\mathrm{a}$ \\
$8 \mathrm{x} / \mathrm{dia}$ & 2.33 & $\mathrm{~b}$ & 1.39 & $\mathrm{~b}$ \\
Solid & 1.57 & $\mathrm{c}$ & 1.50 & $\mathrm{ab}$ \\
\hline $\mathrm{CV}(\%)$ & 5.71 & & 6.32 \\
\hline
\end{tabular}

*Means followed by the same letter do not differ statistically by the Tukey test at $5 \%$ probability. 
Table 2. Number of shoots, length of medium and largest roots $(\mathrm{cm})$ and callus size in 'Pircinque' strawberry explants during rooting in temporary immersion bioreactors.

\begin{tabular}{|c|c|c|c|c|c|c|c|c|}
\hline & $\begin{array}{r}\text { Number } \\
\text { shoots }\end{array}$ & & $\begin{array}{l}\text { Length of } \\
\text { largest root }\end{array}$ & & $\begin{array}{l}\text { Length of } \\
\text { medium roo }\end{array}$ & & \multicolumn{2}{|c|}{ Size of callus } \\
\hline \multicolumn{9}{|c|}{ Culture medium } \\
\hline MS & 2.78 & $a^{*}$ & 1.73 & $\mathrm{a}$ & 1.42 & ns & 1.36 & ns \\
\hline KNOP & 2.25 & $\mathrm{~b}$ & 1.42 & $\mathrm{~b}$ & 1.26 & & 1.29 & \\
\hline \multicolumn{9}{|c|}{ Immersion times } \\
\hline $5 \mathrm{x} / \mathrm{dia}$ & 2.67 & $\mathrm{a}$ & 1.89 & $\mathrm{a}$ & 1.61 & $\mathrm{a}$ & 1.31 & $\mathrm{~b}$ \\
\hline $8 \mathrm{x} / \mathrm{dia}$ & 2.66 & $\mathrm{a}$ & 1.69 & $\mathrm{a}$ & 1.32 & $\mathrm{~b}$ & 1.22 & $\mathrm{~b}$ \\
\hline Solid & 2.10 & $\mathrm{~b}$ & 1.00 & $\mathrm{~b}$ & 1.00 & $\mathrm{c}$ & 1.48 & $\mathrm{a}$ \\
\hline CV (\%) & 17.69 & & 18.22 & & 16.01 & & 10.41 & \\
\hline
\end{tabular}

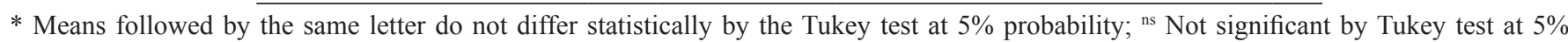
probability of error.

\begin{tabular}{|c|c|c|c|c|c|}
\hline \multicolumn{3}{|c|}{ KNOP (KNOP, 1865) modified } & \multicolumn{3}{|c|}{ MS (Murachige \& Slroog 1962) } \\
\hline \multicolumn{3}{|c|}{ Macromtrients of KNOP cuture medinn } & \multicolumn{3}{|c|}{ Macromurients of MS cultre medinn } \\
\hline Solttion & Conposition & Concentation $\left(m g \mathrm{~L}^{-1}\right)$ & Solution & Composition & Concentration $\left(m g \mathrm{~L}^{-1}\right)$ \\
\hline A & $\mathrm{Ca}(\mathrm{NO})$ & 500 & $A$ & NHWO & 1650 \\
\hline$B$ & $\mathrm{KNO}$, & 125 & $B$ & $\mathrm{KNO}$ & 1900 \\
\hline $\mathrm{C}$ & $\mathrm{MgSO}_{2}, \mathrm{H}-\mathrm{O}$ & 125 & C & $\mathrm{CaCl}, 2 \mathrm{H}=\mathrm{O}$ & 440 \\
\hline $\mathrm{D}$ & $\mathrm{KHPO}$ & 250 & $\mathrm{G}$ & $\mathrm{MgSO}, \mathrm{THO}$ & 370 \\
\hline$E$ & $\mathrm{FeCl} 6 \mathrm{H} O \mathrm{O}$ & 125 & $\mathrm{H}$ & $\mathrm{KH} \mathrm{PO}_{4}$ & 170 \\
\hline \multicolumn{3}{|c|}{ Micronutients of MS culhre medim } & \multicolumn{3}{|c|}{ Mrronutients of MS cuhre medim } \\
\hline Solution & Composition & Concentation $\left(m g \mathrm{~L}^{-1}\right)$ & Schution & Composition & Concentration $\left(m g \mathrm{~L}^{-1}\right)$ \\
\hline \multirow{7}{*}{ D } & $\mathrm{MnSO} \cdot \mathrm{HO}$ & 16,9 & \multirow{7}{*}{ D } & $\mathrm{MrnSO} \cdot \mathrm{HO}$ & 16,9 \\
\hline & $\mathrm{ZnSO} .7 \mathrm{HO}$ & 86 & & $\mathrm{ZnSO}, \mathrm{HH}=\mathrm{O}$ & 86 \\
\hline & $\mathrm{HBO}$ & 6,2 & & $\mathrm{HBO}$ & 6.2 \\
\hline & $\mathrm{K} 1$ & 0,83 & & $\mathrm{~K} 1$ & 0,83 \\
\hline & $\mathrm{Na}-\mathrm{MoO} \cdot 2 \mathrm{H} \mathrm{O}$ & 0.25 & & $\mathrm{Na} \cdot \mathrm{M} 6 \mathrm{O} \cdot 2 \mathrm{HO}$ & 0.25 \\
\hline & $\mathrm{CuSO}, \mathrm{SH}-\mathrm{O}$ & 0,025 & & $\mathrm{CuSO}, 5 \mathrm{HO}$ & 0,025 \\
\hline & $\mathrm{CoC} 1.6 \mathrm{HO}$ & 0,025 & & $\mathrm{COCl}, \mathrm{GH} \mathrm{O}$ & 0,025 \\
\hline \multirow{2}{*}{$F$} & $\mathrm{FeSO} .7 \mathrm{HO}$ & 27.8 & \multirow{2}{*}{$F$} & $\mathrm{FeSO}, \mathrm{TH}=\mathrm{O}$ & 27.8 \\
\hline & $\mathrm{Na}$ EDTA $2 \mathrm{H} \mathrm{O}$ & 37,3 & & $\mathrm{Na}$ EDTA.2HO & 37,3 \\
\hline \multicolumn{3}{|c|}{ Vitem ins froen MS culhre medirn } & \multicolumn{3}{|c|}{ Vitemins from MS culhre medinn } \\
\hline Soltion & Conposition & Concentration $\left(m g \mathrm{~L}^{-1}\right)$ & Solution & Composition & Comcentration $\left(m \mathrm{gL}^{-1}\right)$ \\
\hline \multirow{4}{*}{$\mathrm{E}$} & Glycine & 2 & \multirow{4}{*}{ E } & Gycine & 2 \\
\hline & Nicotinic acid & 0,5 & & Nrotinic acd & 0.5 \\
\hline & Pysidoxine & 0,5 & & Pyridoxine & 0.5 \\
\hline & Thiamine & 0.5 & & Thiemine & 0.5 \\
\hline
\end{tabular}

Figure 4 - Comparison of nutrients from modified KNOP culture media (KNOP, 1865) and MS (Murashige and Skoog, 1962). 


\section{Conclusions}

The use of a temporary immersion bioreactor system is an efficient technique for the multiplication and rooting of explants of strawberry cv. Pircinque, when compared to the conventional method of micropropagation with the use of a solid culture medium.

The liquid MS culture medium in contact five times a day with explants of the 'Pircinque' strawberry favors the increase of the number of leaves and roots and length of the explant and of new shoots.

\section{References}

BARUZZI, G.; BALLINI, L.; BARONI, G.; BIROLLI, M. Updates on Italian strawberry breeding programs coordinated by CREA-FRF. Acta Horticulturae, Wageningen, v.1156, n.1, p.179-184, 2017.

CAMOLESI, M.R.; FARIA, R.T.; NEVES, C.S.V.J.; MARTINS, A.N. Volume do frasco e consistência do meio de cultura na multiplicação in vitro da bananeira 'Maçã'. Ciência Rural, Santa Maria, v.40, p.255-260, 2010.

DEBIASI, C. Utilização de biorreatores de imersão temporária em uma biofábrica de cultura de tecidos. In: GERALD, L. T. S. (Org.). Biofábrica de plantas: produção industrial de plantas in vitro. São Paulo: Antiqua, 2011. p. 99-115.

DEBNATH, S.C. Molecular approaches for monitoring clonal fidelity and epigenetic variation in in vitro-derived strawberry plants. Acta Horticulturae, Wageningen, v.1156, p.83-88, 2017.

DEBNATH, S.C.; MCKENZIE, D.; BISHOP, G.; PERCIVAL, D. Strategic approaches to propagate berry crop nuclear stocks using a bioreactor. Acta Horticulturae, Wageningen, v.1113, p.47-52, 2014.

DEZAN, L.F.; CANASSA, F.; SOUZA-LEAL, T.; DIOGO, J.A.; MASSARO, R.; CORDEIRO, G.M.; PEDROSO-DE-MORAES, C. Crescimento in vitro de Schomburgkia gloriosa Lindl. em meio de cultivo simplificados. Idesia, Arica, v.30, n.2, 2012.

FAEDI, W.; BARUZZI, G.; LUCCHI, P.; MAGNANI, S.; CARULLO, A.; MALTONI, M.L.; MIGANI, M.; SBRIGHI, P. The new 'Pircinque' strawberry cultivar released under Italy's PIR Project. Acta Horticulturae, Wageningen, v.1049, n.1, p.961-1966, 2014.

FOGAÇA, C.M.; SANT'ANNA-SANTOS, B.F.; CORDEIRO, D.C.; CORREIA, T.D.; FINGER, F.L.; OTONI, W.C.; CARGNIN, A. Microtuberização in vitro de cultivares de mandioca: aspectos morfológicos e anatômicos. Acta Botânica Brasílica, São Paulo, v.24, n.3, p.624-630, 2010.
FRÓMETA, O.M.; MORGADO, M.M.E.; SILVA, J.A.T.; MORGADO, D.T.P.; GRADAILLE, M.A.D. In vitro propagation of Gerbera jamesonii Bolus ex Hooker f. in a temporary immersion bioreactor. Plant Cell, Tissue and Organ Culture, London, v.129, n.3, p.543-551, 2017.

GAO, M.; JIANG, W.; WEI, S.; LIN, Z.; CAI, B.; YANG, L.; CHEN, L. High-efficiency propagation of Chinese water chestnut [Eleocharis dulcis (Burm. f.) Trin. ex Hensch] using a temporary immersion bioreactor system. Plant Cell, Tissue and Organ Culture, London, v.121, n.3, p.761-772, 2015.

GEORGIEV, V.; SCHUMANN, A.; PAVLOV, A.; BLEY, $\mathrm{T}$. Temporary immersion systems in plant biotechnology. Engineering in life sciences, Weinheim, v.14, n.6, p.607$621,2014$.

GEORGIEVA, L.; TSVETKOV, I.; GEORGIEVA, M.; KONDAKOVA, V. New protocol for in vitro propagation of berry plants by tis bioreactor. Bulgarian Journal of Agricultural Science, Sofia, v.22, n.5, p.745-751, 2016.

HANHINEVA, K.; KOKKO, H.; KARENLAMPI, S. Shoot regeneration from leaf explants of five strawberry (Fragaria $\times$ ananassa) cultivars in temporary immersion bioreactor system. In vitro Cellular \& Developmental Biology, Gaithersburg, v.41, p.826-831, 2005.

NAVROSKI, M.C.; REINIGER, L.R.; PEREIRA, M.O.; CURTI, A.R.; PAIM, A.F. Alongamento in vitro de genótipos de Eucalyptus dunnii Maiden. Cerne, Lavras, v.19, n.4, p.545-550, 2013.

OLIVEIRA, M.L.; XAVIER, A.; FILHO, R.M.P.; REIS, J.P. Efeito do intervalo de imersão e de injeção de ar na multiplicação in vitro de Eucalyptus grandis x Eucalyptus urophylla em biorreator de imersão temporária. Ciência Florestal, Santa Maria, v.24, n.1, p.37-45, 2014.

TAIZ, L.; ZEIGER, E. Fisiologia vegetal. 5.ed. São Paulo: Artmed, 2013. p.164-197.

WILKEN, D., JIMÉNEZ, E.; GERTH, A.; GÓMEZKOSKY, R.; SCHUMANN, A.; CLAUS, D. Effect of immersion systems, lighting, and TIS designs on biomass increase in micropropagating banana (Musa spp. cv. 'Grande naine'AAA). In Vitro Cellular \& Developmental Biology, Gaithersburg, v.50, n.5, p.582-589, 2014. 